\title{
Pengaruh Media Lingkungan dan Kecerdasan Emosional Terhadap Hasil Belajar IPS SMP
}

\author{
DADEK LUKH SAYEKTI DAN MUHSINATUN SIASAH MASRURI \\ Program Studi Pendidikan Ilmu Pengetahuan Sosial \\ Program Pascasarjana Universitas Negeri Yogyakarta \\ dadek.lukh.sayekti@gmail.com, muhsinsiasah@gmail.com
}

\begin{abstract}
Abstrak
Penelitian ini bertujuan mengetahui pengaruh penggunaan media lingkungan sekitar dan kecerdasan emosional terhadap hasil belajar IPS SMP di Kabupaten Cilacap. Penelitian ini menggunakan metode quasi eksperimen dengan desain penelitian faktorial $2 \times 2$. Analisis data menggunakan ANOVA dua jalur pada taraf signifikansi 0,05. Hasil penelitian menunjukkan: (1) terdapat perbedaan signifikan antara hasil belajar peserta didik yang menggunakan media lingkungan sekitar dan powerpoint; (2) terdapat perbedaan signifikan antara hasil belajar peserta didik yang menggunakan media lingkungan sekitar dan powerpoint pada peserta didik dengan kecerdasan emosional tinggi; (3) terdapat perbedaan yang signifikan antara hasil belajar peserta didik yang menggunakan media lingkungan sekitar dan powerpoint pada peserta didik dengan kecerdasan emosional rendah; (4) terdapat interaksi pengaruh penggunaan media pembelajaran dan tingkat kecerdasan emosional terhadap hasil belajar IPS. Penggunaan media lingkungan sekitar lebih sesuai untuk pembelajaran peserta didik dengan kecerdasan emosional tinggi, sedangkan media presentasi powerpoint lebih sesuai untuk pembelajaran peserta didik dengan kecerdasan emosional rendah.
\end{abstract}

Kata Kunci : media pembelajaran, Kecerdasan Emosional, dan hasil belajar

\begin{abstract}
This research aims to determine the effects of using environmental media and emotional intelegences on the learning outcomes of Social Sciences at Junior High School in Cilacap. The research employs a quasi experimental method and utilizes $2 \times 2$ factorial research design. The data analysis is performed using a two-way ANOVA at significance level of 0.05. The findings are: (1) there is a significant difference of the learning outcomes between learners who are taught using environmental media and powerpoint, (2) there is a significant difference of the learning outcomes between learners who are taught using environmental media and powerpoint on the learners who have high intelligence, (3) there is a significant difference of the learning outcomes between learners who are taught using environmental media and powerpoint on the learners who have low intelligence, (4) there is a significant interaction between influence of using environmental media and emotional intelegences on the learning outcomes of Social Studies. The use of environmental media is more appropriate for the social studies learning for learners who have high emotional intelligence. Whereas, powerpoint is more appropriate for learners who have low emotional intelligence.
\end{abstract}

Keywords: learning media, emotional intellegences and learning outcomes 


\section{PENDAHULUAN}

Pendidikan adalah suatu usaha atau kegiatan yang dijalankan dengan sengaja, teratur, dan berencana dengan maksud mengubah atau mengembangkan perilaku yang diinginkan. Sekolah merupakan lembaga yang dijadikan sebagai sarana dalam rangka pencapaian tujuan pendidikan tersebut. Melalui sekolah, peserta didik dapat mempelajari berbagai macam kompetensi yang dibentuk dalam kehidupan melalui proses belajar diharapkan dapat terjadi perubahan bertahap yang sifatnya positif sehingga pada akhirnya peserta didik memiliki keterampilan, kecakapan, dan sikap seperti yang terkandung di dalam falsafah negara. Melalui proses belajar, peserta didik mengenal lingkungannya dan dapat menyesuaikan diri dengan kondisi lingkungan sekitarnya.

Proses pembelajaran pada Kurikulum 2013 untuk jenjang SMP dan SMA atau yang sederajat dilaksanakan dengan menggunakan pendekatan ilmiah (scientific appoach). Pendekatan ilmiah dalam pembelajaran meliputi mengamati, menanya, mengumpulkan data, mengasosiasi, dan menyimpulkan/ mengkomunikasi. Ini sesuai dengan permendikbud No. 65 Tahun 2013 tentang Standar Proses Pendidikan Dasar dan Menengah telah mengisyaratkan tentang perlunya proses pembelajaran yang dipandu dengan kaidah-kaidah pendekatan scientific/ilmiah (Sudrajat, 2013: 1).

Guru merupakan figur yang memegang peranan penting dalam pembelajaran di kelas. Peran utama guru bukan menjadi penyaji informasi yang harus dipelajari oleh peserta didik, melainkan membelajarkan peserta didik tentang cara mempelajari sesuatu secara efektif (learning how to learn). Oleh karena itu pemahaman terhadap materi keilmuan dan kurikulum, teori belajar dan strategi pembelajaran merupakan hal yang mutlak bagi seorang guru. Proses pembelajaran yang menarik dapat mendorong peserta didik aktif berpartisipasi dalam upaya mencapai tujuan pembelajaran.

Pada hakekatnya IPS mempelajari tentang "human beings" (Ellis, 1998: 1) yang peka terhadap keragaman sistem, pola kehidupan, bentuk dan struktur sosial, melalui penemuan makna dalam aktivitasnya mempertemukan kebutuhan-kebutuhan dasar. Berdasarkan struktur kurikulum 2013, bahan kajian IPS meliputi kemampuan memahami seperangkat fakta, konsep, generalisasi tentang sistem sosial dan budaya, manusia, tempat dan lingkungan, perilaku ekonomi dan kesejahteraan, waktu, keberlanjutan dan perubahan, sistem berbangsa dan bernegara. Dengan demikian peranan IPS sangat penting untuk membantu peserta didik mengembangkan pengetahuan, sikap, dan keterampilan sosial agar dapat mengambil bagian secara aktif dalam kehidupannya sebagai anggota masyarakat dan warga negara yang baik.

Keberhasilan upaya pendidikan ditandai dengan adanya suatu perubahan positif pada anak didik. Perubahan tersebut meliputi perubahan pada aspek kognitif, afektif, dan psikomotorik. Untuk mencapai sasaran tersebut seorang guru sebagai tenaga profesional, hendaknya meningkatkan kemampuan peserta didik dengan cara menganalisis kurikulum serta menjabarkannya kedalam materi pembelajaran. Kenyataannnya, banyak dijumpai guru-guru yang belum mampu untuk mengembangkan kurikulum menjadi rencana pembelajaran yang aplikatif.

Belajar pada hakekatnya adalah suatu interaksi antara individu dan lingkungan. Lingkungan menyediakan ransangan (stimulus) terhadap individu dan sebaliknya individu memberikan respons terhadap lingkungan. Dalam proses interaksi itu dapat terjadi perubahan pada diri individu berupa tingkah laku. Dapat juga terjadi, individu menyebabkan perubahan tingkah laku, baik yang positif maupun yang negatif. Hal ini menunjukan, bahwa fungsi lingkungan merupakan faktor yang penting dalam proses belajar mengajar (Hamalik, 2008: 194).

Chiras (1991: 3) menyatakan "The word environmental refers broadly to everything around us: the air, the watter, and the land as well as the plants, animals, and micro organism that in habit them". Kata lingkungan secara luas diartikan sebagai suatu yang ada 
disekitar kita: udara, air, daratan, dan begitu pula tanaman, binatang, dan mikro organisme yang mendiaminya.

Hamalik (2008: 195) menyatakan ada dua istilah yang sangat erat kaitannya tetapi berbeda secara gradual, ialah "alam sekitar" dan "lingkungan". Alam sekitar mencakup segala hal yang ada di sekitar kita, baik yang jauh maupun yang dekat letaknya, baik masa silam maupun yang akan datang tidak terikat pada dimensi waktu dan tempat. Lingkungan adalah sesuatu yang ada di alam sekitar yang memiliki makna dan atau berpengaruh tertentu kepada individu.

Hamalik (2008: 195), menemukan lingkungan (environment) sebagai dasar pengajaran adalah faktor kondisional yang mempengaruhi tingkah laku individu dan merupakan faktor yang penting. Lingkungan belajar/pembelajaran/pendidikan terdiri dari: (1) lingkungan sosial adalah lingkungan masyarakat baik kelompok besar atau kelompok kecil; (2) lingkungan personal meliputi individu-individu sebagai suatu pribadi berpengaruh terhadap individu pribadi lainnya; (3) lingkungan alam (fisik) meliputi semua sumber daya alam yang dapat diberdayakan sebagai sumber belajar; (4) lingkungan kultural mencakup hasil budaya dan teknologi yang dapat dijadikan sumber belajar dan dapat menjadi faktor pendukung pengajaran. Dalam konteks ini termasuk sistem nilai, norma, dan adat kebiasaan.

Sudjana dan Rivai (2009: 209-211) menjelaskan bahwa ada beberapa cara bagaimana mempelajari lingkungan sebagai media dan sumber belajar, yaitu: (1) dengan cara survey; (2) dengan kamping atau berkemah; (3) dengan cara field trip atau karyawisata; (4) dengan cara praktek lapangan; (5) mengundang manusia sumber atau narasumber; (6) melalui proyek pelayanan dan pengabdian pada masyarakat. Guru dan peserta didik secara bersama-sama melakukan kegiatan memberikan bantuan kepada masyarakat, seperti pelayanan, penyuluhan, partisipasi dalam kegiatan masyarakat, dan kegiatan lain yang diperlukan.

Dalam kaitannya dengan kondisi tersebut, maka salah satu media yang digunakan adalah media lingkungan sekitar. Dengan media tersebut diharapkan peserta didik lebih peduli dan peka terhadap lingkungan sekitar baik alam, sosial dan budaya. Dengan penerapan media tersebut diharapkan hasil belajar peserta didik pada mata pelajaran IPS menjadi semakin meningkat.

Penggunaan lingkungan sekitar memungkinkan terjadinya proses belajar yang lebih bermakna (meaningfull learning) sebab anak dihadapkan pada keadaan dan situasi yang sebenarnya. Hal ini dapat memenuhi prinsip pembelajaran kontekstual, sebagai mana dimaksudkan dalam prinsip pembelajaran. Selain itu pemanfaatan lingkungan sebagai media pembelajaran akan mendorong pada penghayatan nilai-nilai atau aspek-aspek kehidupan yang ada di lingkungannya.

Pembelajaran dengan menggunakan media lingkungan sekitar memudahkan peserta didik memahami konsep-konsep yang bersifat abstrak, sehingga dapat menemukan prinsip-prinsip dan konsep-konsep yang pada akhirnya dapat meningkatkan hasil pembelajaran. Media lingkungan sekitar merupakan salah satu media dimana peserta didik mengasimilasikan konsep dan pengetahuan yang diperoleh peserta didik dapat bertahan lebih lama dalam ingatan, meningkatkan penalaran karena mereka harus menganalisa atau memecahkan masalah serta membangkitkan rasa ingin tahu pada peserta didik.

Semua media pada dasarnya dibuat untuk disajikan atau dipresentasikan kepada sasaran. Daryanto (2010: 67) menjelaskan yang membedakan media presentasi dan media pada umumnya adalah bahwa pada media presentasi pesan/materi yang akan disampaikan dikemas dalam sebuah program komputer dan disajikan melalui perangkat alat saji (LCD). Pesan atau materi dikemas bisa berupa teks, gambar, animasi dan video yang dikombinasikan dalam satu kesatuan yang utuh.

Banyak jenis perangkat lunak (software) yang dapat digunakan untuk membuat media presentasi. Jenis software aplikasi yang bersifat open source misalnya program impress yang ada pada Open office. Adapun software aplikasi yang lain yang dapat digunakan mis- 
alnya program visual basic, makromedia flash, direktor, authorware, dream weaver dan masih banyak lagi. Diantara sekian banyak jenis software tersebut, salah satunya yang dapat digunakan di kalangan pendidik (khususnya guru) adalah Microsoft Powerpoint. Media presentasi powerpoint mudah digunakan dan praktis.

Media dalam pembelajaran merupakan hal yang sangat penting. Ketidakjelasan bahan yang disamapaikan dapat dibantu dengan menghadirkan media. Kerumitan bahan pada pembelajaran dapat disederhanakan. Keabstrakan bahan dapat dikonkritkan. Dengan demikian siswa lebih mudah mencerna materi. Hal ini dapat terjadid alam pembelajaran IPS yang mengakibatkan peserta didik cepat merasa bosan, lelah dan kurang suka karena bahan pelajaran yang rumit. Ataupun penjelasan guru yang sukar dicerna dan dipahami oleh peserta didik. Akibatnya pembelajaran tidak efektif dan hasil belajar menjadi kurang maksimal. Media sebagai alat bantu dan sumber belajar mempunyai fungsi melancarakan jalan menuju tercapainya tujuan pembelajaran.

Cakupan Materi IPS yang luas dari berbagai disiplin ilmu mengakibatkan pembelajaran IPS sangat bervariasi dan beragam. Metode-metode pembelajaran IPS SMP diarahkan pada pengaitan langsung dengan kenyataan sehari-hari yang dialami oleh peserta didik. Keberhasilan metode pembelajaran dengan tetap menjadikan peserta didik sebagai orang yang aktif dan pusat belajar (student center) dapat menjembatani kesenjangan antara keluasan cakupan materi IPS dan alam pikir peserta didik yang masih dalam fase operasional konkrit. Stimulus lingkungan sekitar dapat menggugah rasa ingin tahu peserta didik, di samping respon yang meningkat pada proses belajar, peserta didik dapat memahami materi dengan mengaitkan langsung pada pengalaman hidup nyata. Hasil belajar yang meliputi tiga ranah dapat ditingkatkan dengan tindakan visualisasi konsep (materi) IPS, dengan kata lain peserta didik diperlihatkan secara kasat mata perihal kehidupan yang terjadi di lingkungan sekitar.

Media pembelajaran bukan satu-satunya penentu keberhasilan belajar. Banyak faktor internal maupun eksternal yang juga memberi sumbangan. Salah satu faktor internal tersebut adalah kecerdasan emosional. Seseorang yang tinggi kualitas kecerdasan emosional dalam kinerjanya akan tampak adanya keuletan, selalu dapat menahan diri dari frustasi atau himpitan keadaan dalam mencapai atau memperjuangkan sesuatu. Dengan kata lain siapa yang memiliki kecerdasan emosional pada umumnya selalu gigih, ulet, konsisten, tahan uji, handal dalam menghadapi situasi paling pahit dan berat.

Kecerdasan emosional sangat dipengaruhi oleh lingkungan, tidak bersifat menetap, dapat berubah-ubah setiap saat. Untuk itu peranan lingkungan terutama orang tua pada masa kanak-kanak sangat mempengaruhi dalam pembentukan kecerdasan emosional. Keterampilan EQ bukanlah lawan keterampilan IQ atau keterampilan kognitif, namun keduanya berinteraksi secara dinamis, baik pada tingkatan konseptual maupun di dunia nyata. Selain itu, EQ tidak begitu dipengaruhi oleh faktor keturunan. (Shapiro, 1998: 9-10).

Salovey (lewat Goleman 1999: 57-59) menempatkan kecerdasan pribadi Gardner dalam definisi dasar tentang kecerdasan emosional yang dicetuskannya dan memperluas kemampuan tersebut menjadi lima kemampuan utama, yaitu: (1) mengenali emosi diri/ kesadaran diri; (2) mengelola emosi/ pengaturan diri; (3) memotivasi diri sendiri; (4) mengenali emosi orang lain/ empati; (5) membina hubungan/ ketrampilan sosial. Dalam hal ini yang dimaksud dengan kecerdasan emosional adalah kemampuan peserta didik untuk mengenali emosi diri, mengelola emosi diri, memotivasi diri sendiri, mengenali emosi orang lain (empati) dan kemampuan untuk membina hubungan (kerjasama) dengan orang lain.

Kecerdasan Emosional dapat diartikan sebagai suatu kemampuan individu untuk memahami, menguasai dan mengendalikan pergolakan pikiran dan perasaan dirinya maupun orang lain menghadapi suatu situasi untuk mencapai tujuan tertentu dalam kehidupannya. Ciri-ciri individu yang memiliki kecerdasan emosi tinggi memiliki kemam- 
puan dan keterampilan dalam mengendalikan dirinya, memiliki semangat dan ketekunan yang tinggi, mampu memotivasi dirinya dalam mengerjakan sesuatu dan mampu berinteraksi baik dengan orang lain. Sedangkan ciri-ciri individu yang memiliki kecerdasan emosi rendah yaitu mempunyai emosi yang tinggi, cepat bertindak berdasarkan emosinya, tidak sensitif dengan perasaan orang lain dan biasanya mempunyai kecenderungan untuk menyakiti dan memusuhi orang lain. Untuk mengukur EQ secara objektif, sampai saat ini belum ditemukan pengukuran yang akurat, akan tetapi kita dapat mengukur EQ secara subjektif, dengan mengukur EQ diri sendiri menggunakan angket atau memperkirakan EQ seseorang dari kehidupannya sehari-hari. Salah satu cara untuk mengukur EQ seseorang adalah menggunakan parameter kerangka kerja kecerdasan emosi yang dirancang oleh Daniel Goleman.

Seseorang yang cerdas dalam mengendalikan emosinya tentu lebih berhasil dalam belajar, dibandingkan dengan yang kurang cerdas mengendalikan emosinya. Seorang guru dalam proses pembelajaran IPS belum mempertimbangkan kecerdasan emosional sebagai faktor yang ikut berperan dalam upaya mencapai keberhasilan belajar. Pembelajaran lebih mengutamakan kecerdasan intelektual (IQ) dan mengabaikan kecerdasan lain seperti kecerdasan emosional (EQ), maupun kecerdasan spiritual (SQ). Padahal dalam mencapai kesuksesan belajar kecerdasan emosional dan spiritual lebih berperan daripada kecerdasan intelektual pada diri peserta didik.

Kualitas proses belajar peserta didik dengan mengunakan media menunjukan peningkatan/perbaikan bila dibandingkan dengan pembelajaran konvensional. Demikian juga unjuk kerja guru lebih kreatif dan aktif serta mempengaruhi suasana pembelajaran menjadi lebih menyenangkan. Kecerdasan Emosional dapat memberikan dorongan yang positif dalam menerima pembelajaran. Pada aspek hasil belajar memperlihatkan kemajuan yang signifikan setelah diberi tindakan pemanfaatan lingkungan sekitar sebagai media pembelajaran.
Masalah pembelajaran yang terkait dengan lambatnya pemahaman peserta didik terhadap konsep dan teori yang bersifat abstrak perlu diatasi. Jika hal ini dibiarkan, efektivitas dan efisiensi pembelajaran akan rendah. Pada akhirnya hal ini akan mengakibatkan rendahnya hasil belajar peserta didik. Oleh karena itu perlu dicari upaya yang sistematis guna meningkatkan efektivitas dan efisiensi pembelajaran. Hal ini mungkin akan terjadi jika perencanaan pembelajaran dikembangkan dalam bentuk individual. Dengan demikian setiap peserta didik dapat belajar dan mencapai kemajuan sesuai dengan kemampuan potensialnya masing-masing. Salah satu upayanya adalah menggunakan media lingkungan sekitar dan powerpoint sebagai salah satu alternatif media pembelajaran yang efektif, inovatif dan menyenangkan.

\section{METODE}

\section{Jenis Penelitian}

Penelitian ini menggunakan jenis penelitian quasi experimental research atau eksperimen semu. Desain penelitian yang digunakan adalah factorial design atau rancangan faktorial 2x2. Sukardi (2012: 187), menyatakan desain faktorial merupakan suatu tindakan terhadap satu variabel atau lebih yang dimanipulasi secara simultan agar dapat mempelajari pengaruh setiap variabel terhadap variabel terikat atau pengaruh yang diakibatkan adanya interaksi antara beberapa variabel. Melalui desain ini dapat dibandingkan pengaruh penggunaan media lingkungan sekitar dengan strategi media presentasi powerpoint terhadap hasil belajar IPS ditinjau dari Kecerdasan Emosi tinggi dan Kecerdasan Emosi rendah.

\section{Waktu dan Tempat Penelitian}

Penelitian ini dilaksanakan di SMP Negeri 5 Cilacap dan SMP Negeri 2 Cilacap Propinsi Jawa Tengah. Penelitian ini dilaksanakan pada semester genap tahun ajaran 2013/ 2014 yaitu bulan Maret s/d April 2014.

\section{Populasi dan Sampel}

Populasi dalam penelitian ini adalah se- 
luruh sekolah yang menggunakan Kurikulum 2013. Sampel yang diambil adalah peserta didik kelas VII SMP Negeri 5 Cilacap (256 peserta didik) dan SMP Negeri 2 Cilacap (258 peserta didik). Peneliti mengambil sampel satu kelas setiap sekolah yaitu di SMP Negeri 5 Cilacap pada kelas VIID berjumlah 32 peserta didik (media lingkungan sekitar) dan SMP Negeri 2 Cilacap pada kelas VIIF yang berjumlah 32 peserta didik (media presentasi powerpoint). Pemilihan sampel menggunakan teknik simple random sampling, karena pengambilan anggota sampel dari populasi dilakukan secara acak tanpa memperhatikan strata yang ada dalam populasi itu dan anggota populasi dianggap homogen (Sugiyono, 2009: 120).

\section{Prosedur}

Jenis penelitian kuantitatif, dengan data primer diperoleh dari tes hasil belajar IPS kuesioner. Instrumen hasil belajar dan kuesioner terlebih dahulu diuji validitasnya menggunakan Confirmatory Factor Analysis, dengan tingkat signifikansi KMO and Bartlet's disyarakat harus lebih dari 0,5 dan Uji Reliabilitas menggunakan Alpha Cronbach disyaratkan harus lebih dari 0,7 (Ghozali, 2011: 56). Selanjutnya konstruk instrumen yang telah memenuhi persyaratan digunakan untuk mengumpulkan data dari 64 responden. Data yang terkumpul kemudian diuji asumsi klasik, yang meliputi uji normalitas dan uji homogenitas. Teknik analisis data yang digunakan adalah analisis varian (Anova) dua jalur dengan $\alpha=0.05$.

\section{Data, Instrumen, Teknik Pengumpulan Data dan Teknik Analisis Data}

\section{Data}

Data primer yang dikumpulkan adalah data hasil belajar IPS dengan tes uraian dan data kecerdasan emosional dengan kuesioner. Pertanyaan dalam tes hasil belajar terkait dengan materi pembelajaran pada BAB 5 semester 2 kelas VII. Serta dalam pertanyaan kuesioner terkait dengan variabel kecerdasan emosional.

\section{Instrumen}

Instrumen penelitian ini adalah tes hasil belajar dengan kriteria penilaian hasil belajar dengan menjumlahkan jumlah benar di bagi empat. Kuesioner dengan kriteria penilaian angket menggunakan skala Likert. Skala likert yang digunakan dalam penelitian ini adalah 4 skala likert. Data terkumpul dari 64 responden dengan jumlah pertanyaan uraian sebanyak 15 item pertanyaan, serta kuesioner kecerdasan emosional sebanyak 28 item pertanyaan terdiri dari 5 pertanyaan indikator mengenal emosi diri, 6 pertanyaan indikator mengelola emosi, 5 pertanyaan indikator memotivasi diri sendiri, 6 pertanyaan indikator mengenal emosi orang laian dan 6 pertanyaan indikator membina hubungan. Instrumen kuesioner terlebih dahulu diuji validitasnya menggunakan Confirmatory Factor Analysis, dengan tingkat signifikansi KMO and Bartlet's disyarakat harus lebih dari 0,5. Uji Reliabilitas menggunakan Alpha Cronbach disyaratkan harus lebih dari 0,7.

\section{Teknik Analisis Data}

Teknik analisis data yang digunakan dalam penelitian ini adalah teknik statistik deskriptif. Analisis deskriptif dalam penelitian ini meliputi analisis karakteristik responden, deskriptif kategori variabel, dan analisis statisitik deskriptif yang terdiri dari: nilai maksimal, minimal, mean, modus, median dan standar deviasi, serta kategorisasi jawaban responden. Pada bagian ini penulis akan menganalisa data tersebut satu persatu yang didasarkan pada jawaban responden yang dihimpun berdasarkan tes hasil belajar dan kuesioner yang telah diisi oleh responden selama penelitian berlangsung.

Penelitian ini menggunakan Anova dua jalur untuk analisis datanya. Sebelum dilakukan Anova dua jalur, terlebih dahulu dilakukan uji asumsi klasik (uji prasyarat analisis) yang terdiri dari uji normalitas, dan uji homogenitas. Apabila uji asumsi klasik terpenuhi, maka uji hipotesis dapat dilakukan.

\section{HASIL DAN PEMBAHASAN}

Hasil Rangkuman data penelitian ditunjukkan oleh Tabel 1 berikut. 
Tabel Tabel 1. Rangkuman Data Penelitian

\begin{tabular}{lrrrr}
\hline & \multicolumn{2}{c}{ Hasil belajar } & \multicolumn{2}{c}{ Kecerdasan emosional } \\
& Eksperimen & Kontrol & Eksperimen & Kontrol \\
\hline Jumlah & 32 & 32 & 32 & 32 \\
Nilai Tertinggi & 8.29 & 8.21 & 103 & 99 \\
Nilai Terendah & 6.45 & 6.45 & 70 & 63 \\
Mean & 7.76 & 7.62 & 90 & 81 \\
Modus & 8.29 & 7.27 & 103 & 79 \\
Median & 8.01 & 7.58 & 91 & 81 \\
\hline
\end{tabular}

Hasil prasyarat analisa data. Uji normalitas dan homogenitas sebaran data ditunjukkan oleh Tabel 2 dan 3 berikut.

Tabel 2. Rangkuman Hasil Uji Normalitas

\begin{tabular}{rrrr}
\hline & \multicolumn{1}{c}{ Data } & $\begin{array}{c}\text { Asymp. Sig } \\
\text { (2-tailed) }\end{array}$ & \multicolumn{1}{c}{ Keterangan } \\
\hline $\begin{array}{c}\text { Ekspe- } \\
\text { rimen }\end{array}$ & Hasil Belajar & 0.218 & Asymp. Sig (2-tailed) $>0.05=$ normal \\
& Kecerdasan Emosional & 0.845 & Asymp. Sig (2-tailed) $>0.05=$ normal \\
Kontrol & Hasil Belajar & 0,206 & Asymp. Sig (2-tailed) $>0.05=$ normal \\
& Kecerdasan Emosional & 0.896 & Asymp. Sig (2-tailed) $>0.05=$ normal \\
\hline
\end{tabular}

Tabel 3. Rangkuman Hasil Uji Homogenitas

\begin{tabular}{rrrrc}
\hline No & Data & $\begin{array}{c}\text { Levence } \\
\text { statistic }\end{array}$ & \multicolumn{1}{l}{ Sig } & Keterangan \\
\hline 1 & Hasil Belajar & 0.533 & 0.468 & Sig. 0,468 > 0,05 = homogen \\
2 & Kecerdasan Emosional & 0.421 & 0.519 & Sig. 0,519>0,05 = homogen \\
\hline
\end{tabular}

Hasil Anova dua jalur dapat dilihat pada Tabel 4 berikut:

Hipotesis 1

Tabel 4. Hasil Uji Anova Dua Jalur

Perbandingan Hasil Belajar Antara Penggunaan Media Lingkungan Sekitar dan Powerpoint

\begin{tabular}{lrrr}
\hline \multicolumn{1}{c}{ Media } & Rata-rata & $\mathrm{F}_{\text {hitung }}$ & $\mathrm{p} / \mathrm{sig}$ \\
\hline Lingkungan sekitar & 7.76 & 4.074 & 0.048 \\
Media presentasi powerpoint & 7.62 & & \\
\hline
\end{tabular}

Berdasarkan Tabel 4. diperoleh bahwa hasil Uji Anova dua jalur tersebut diketahui bahwa rata-rata hasil belajar dengan media lingkungan sekitar adalah 7.76 dan rata-rata hasil belajar 
dengan media powerpoint adalah 7.62 dan diperoleh nilai $\mathrm{F}_{\text {hitung }}$ sebesar 4.074 dengan $\mathrm{p}=0.048$ pada taraf signifikansi $\alpha=0.05(\mathrm{p}=0.048>0.05)$. Dengan demikian $\mathrm{H}_{0}$ ditolak dan $\mathrm{H}_{\mathrm{a}}$ diterima, sehingga dapat disimpulkan bahwa terdapat perbedaan yang signifikan hasil belajar antara peserta didik yang belajar dengan menggunakan media lingkungan sekitar dan media presentasi powerpoint. Besarnya pengaruh media lingkungan sekitar dan media presentasi powerpoint terhadap hasil belajar sebesar 23\%, sedangkan sisanya sebesar 77\% dipengaruhi oleh faktor lain yang tidak termasuk dalam penelitian ini.

Berdasarkan pendapat dari Slameto (2010: 54), faktor-faktor yang mempengaruhi belajar yaitu faktor interen dan ekstern. Faktor intern adalah faktor yang ada dalam diri individu yang sedang belajar misalnya jasmani, psikologis dan kelelahan. Sedangkan faktor ekstern adalah faktor yang ada di luar individu misalnya keluarga, sekolah, dan masyarakat. Dari faktor yang ada dimungkinkan ada yang tidak terpenuhi atau tidak sesuai dengan suasana hati individu.

\section{Hipotesis 2}

\section{Tabel 5. Hasil Uji Anova Dua Jalur Rata-Rata Hasil Belajar IPS Pada Peserta didik Dengan Kecerdasan Emosional Tinggi}

\begin{tabular}{llll}
\hline \multicolumn{1}{c}{ Media } & Rata-rata & $\mathrm{F}_{\text {hitung }}$ & $\mathrm{p} / \mathrm{sig}$ \\
\hline Lingkungan sekitar & 8.19 & & \\
Media presentasi powerpoint & 7.54 & 53.694 & 0.000 \\
\hline
\end{tabular}

Berdasarkan Tabel 5. diperoleh bahwa hasil Uji Anova dua jalur tersebut diketahui bahwa rata-rata hasil belajar dengan media lingkungan sekitar adalah 8.19 dan rata-rata hasil belajar dengan media powerpoint adalah 7.54 dan diperoleh nilai $F_{\text {hitung }}$ sebesar 53.69 dengan $p=0.000$ pada taraf signifikansi $\alpha=0.05(\mathrm{p}=0.000<0.05)$. Dengan demikian $\mathrm{H}_{0}$ ditolak dan $\mathrm{H}_{\mathrm{a}}$ diterima, sehingga dapat disimpulkan bahwa terdapat perbedaan hasil belajar antara penggunaan media lingkungan sekitar dan media presentasi powerpoint pada peserta didik yang mempunyai kecerdasan emosional tinggi.

\section{Hipotesis 3}

Tabel 6. Hasil Uji Anova Dua Jalur Rata-Rata Hasil Belajar IPS Pada Peserta didik Dengan Kecerdasan Emosional Rendah

\begin{tabular}{llll}
\hline \multicolumn{1}{c}{ Media } & Rata-rata & $\mathrm{F}_{\text {hitung }}$ & $\mathrm{p} / \mathrm{sig}$ \\
\hline Lingkungan sekitar & 7.20 & \multirow{2}{*}{6.624} & 0.015 \\
Media presentasi powerpoint & 7.70 & & \\
\hline
\end{tabular}

Berdasarkan Tabel 6. diperoleh bahwa hasil Uji Anova dua jalur tersebut diketahui bahwa rata-rata hasil belajar dengan media lingkungan sekitar adalah 7.20 dan rata-rata hasil belajar dengan media powerpoint adalah 7.70 dan diperoleh nilai $F_{\text {hitung }}$ sebesar 6.624 dengan $p=0.015$ pada taraf signifikansi $\alpha=0.05(\mathrm{p}=0.015<0.05)$. dengan demikian $\mathrm{H}_{0}$ ditolak dan $\mathrm{H}_{\mathrm{a}}$ diterima, sehingga dapat disimpulkan bahwa terdapat perbedaan hasil belajar antara penggunaan media lingkungan sekitar dan media presentasi powerpoint pada peserta didik yang mempunyai kecerdasan emosional rendah. 


\section{Hipotesis 4}

Tabel 7. Hasil Uji Anova Dua Jalur Interaksi Antara Penggunaan Media Pembelajaran Dan Kecerdasan Emosional dan Hasil Belajar

\begin{tabular}{lllll}
\hline \multicolumn{1}{c}{ Media } & \multicolumn{1}{c}{ Kecerdasan emosional } & Rata-rata & $\mathrm{F}_{\text {hitung }}$ & p/sig \\
\hline \multirow{2}{*}{ Lingkungan sekitar } & Kecerdasan emosional tinggi & 8.19 & & \\
& Kecerdasan emosional rendah & 7.20 & & \\
\cline { 2 - 4 } Media presentasi & Kecerdasan emosional tinggi & 7.54 & 30.394 & 0.000 \\
powerpoint & Kecerdasan emosional rendah & 7.70 & & \\
\hline
\end{tabular}

Berdasarkan Tabel 7. diperoleh bahwa hasil Uji Anova dua jalur tersebut Diperoleh nilai $\mathrm{F}_{\text {hitung }}$

sebesar 30.394 dengan $p=0.000$ taraf signifikansi $\alpha=0.05(p=0.000<0.05)$. Dengan demikian Ho ditolak dan Ha diterima, sehingga dapat disimpulkan bahwa terdapat pengaruh interaksi penggunaan media pembelajaran dan kecerdasan emosional terhadap hasil belajar IPS. Besarnya pengaruh media pembelajaran dan kecerdasan emosional terhadap hasil belajar sebesar $44.2 \%$ ( dilihat pada R Squared), sedangkan sisanya sebesar 55.8\% dipengaruhi oleh faktor lain yang tidak termasuk dalam penelitian ini.

Tabel 7 dan Gambar 1 menunjukkan pengaruh dan interaksi dari media pembelajaran dan Kecerdasan Emosional terhadap hasil belajar IPS yang diperoleh peserta didik, yaitu bahwa peserta didik dengan Kecerdasan Emosional tinggi yang belajar menggunakan media lingkungan sekitar mempunyai nilai rata-rata lebih tinggi dari peserta didik dengan Kecerdasan Emosional tinggi yang belajar menggunakan media powerpoint. Sedangkan peserta didik dengan Kecerdasan Emosional rendah yang belajar menggunakan media lingkungan sekitar mempunyai nilai rata-rata lebih rendah dari peserta didik dengan Kecerdasan Emosional rendah yang belajar menggunakan media powerpoint.

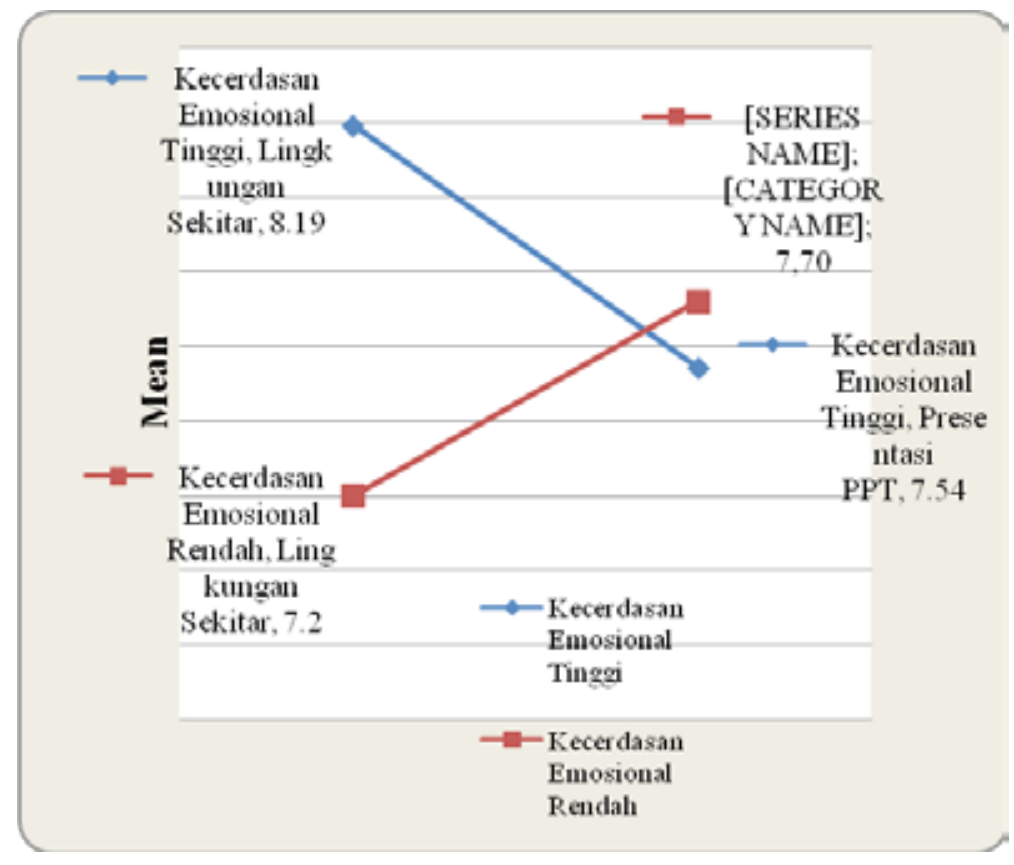

Gambar 1. Grafik Interaksi Pembelajaran dan Kecerdasan Emosional 
Penelitian ini juga membuktikan bahwa faktor Kecerdasan Emosional perlu diperhatikan karena terbukti bahwa Kecerdasan Emosional berpengaruh terhadap hasil belajar IPS. Hasil uji hipotesis menggunakan ANOVA pada penggunaan media pembelajaran terhadap hasil belajar IPS menunjukkan bahwa media pembelajaran berpengaruh signifikan terhadap hasil belajar IPS. Hal ini membuktikan bahwa hasil belajar IPS peserta didik yang belajar dengan menggunakan media lingkungan sekitar lebih tinggi dibandingkan dengan hasil belajar IPS peserta didik yang belajar dengan menggunakan media powerpoint. Hasil tersebut cukup beralasan karena peserta didik yang menggunakan media lingkungan sekitar mendapat pengalaman langsung di lapangan.

Media lingkungan sekitar lebih efektif dan menarik untuk pembelajaran IPS pada peserta didik yang mempunyai tingkat kecerdasan emosional tinggi. Sedangkan untuk penggunaan media presentasi powerpoint, lebih efektif dan menarik untuk pembelajaran IPS pada peserta didik yang mempunyai kecerdasan emosional rendah. Di samping itu masih terdapat faktor-faktor lain yang mempengaruhi hasil belajar, antara lain minat, motivasi, kondisi fisik, metode pembelajaran, lingkungan tempat tinggal, dan sebagainya.

Hal tersebut cukup beralasan karena peserta didik yang memiliki kecerdasan emosional tinggi akan memiliki kepribadian yang stabil dan lebih tahan uji, artinya peserta didik tersebut tidak mudah dipengaruhi oleh hal-hal yang berada di luar jangkauan logika seperti pandangan bahwa pembelajaran IPS merupakan pelajaran yang sulit atau hal-hal intern dan ektern yang berhubungan dengan perasaan seperti cinta, perselisihan dan sebagainya. Sedangkan peserta didik yang memiliki kecerdasan emosional rendah cenderung memiliki kepribadian yang lemah dan mudah putus asa.

Demikian pentingnya faktor emosi dalam menentukan keberhasilan belajar peserta didik, maka Depoter, Reardon, dan SingerNourie, dalam buku Quantum teaching: Orchestrating Student Success, menyarankan agar guru memahami emosi peserta didik mereka. Dengan memperhatikan dan memahami emosi peserta didik, akan membantu guru mempercepat proses pembelajaran yang lebih bermakna dan permanen. Memperhatikan dan memahami emosi peserta didik berarti membangun ikatan emosional, dengan menciptakan kesenangan dalam belajar, menjalin hubungan, dan menyingkirkan segala ancaraman dari suasana belajar.

Melalui kecerdasan emosional, seseorang dapat menempatkan emosinya pada porsi yang tepat, memilih kepuasan dan mengatur suasana hati. Sedangkan kecerdasan emosional merupakan komponen yang membuat seseorang menjadi pintar menggunakan emosi. Maka peserta didik yang memiliki kecerdasan emosional tinggi cenderung dapat membangun pengetahuan tanpa bimbingan dari guru, sedangkan peserta didik yang memiliki kecerdasan emosionla rendah harus diberi bimbingan dalam menemukan konten atau konsep.

Oleh karena bervariasinya kecerdasan emosional yang dimiliki peserta didik, maka penggunaan media pembelajaran hendaknya disesuaikan dengan tujuan pembelajaran, materi yang diajarkan, kondisi dan situasi lingkungan serta kecerdasan emosional. Sehingga materi yang disampaikan mampu di serap dan dimaknai peserta didik.

\section{SIMPULAN}

Dari pembahasan tersebut dapat disimpulkan: (1) Hasil belajar IPS peserta didik yang belajar dengan menggunakan media lingkungan sekitar lebih tinggi dibandingkan dengan hasil belajar IPS peserta didik yang menggunakan media powerpoint; (2) Penggunaan media lingkungan sekitar lebih sesuai untuk pembelajaran IPS pada peserta didik yang mempunyai kecerdasan emosional tinggi; (3) Penggunaan media presentasi powerpoint lebih sesuai untuk pembelajaran IPS pada peserta didik yang mempunyai kecerdasan emosional rendah; (4) Terdapat interaksi pengaruh penggunaan media pembelajaran dan kecerdasan emosional. Besarnya pengaruh media pembelajaran dan kecerdasan emosional terhadap hasil belajar 
sebesar $44.2 \%$

Dari pembahasan tersebut, ada beberapa saran yang dapat disampaikan: (1) Dalam penggunaan lingkungan sekitar sebagai salah satu media pembelajaran seyogyanya sekolah mengupayakan untuk bekerjasama dengan lingkungan sekitar sekolah atau tempat-tempat yang dapat digunakan sebagai media lingkungan sekitar; (2) Guru diharapkan mampu mengenal pribadi peserta didik dari segi kecerdasan emosional dengan baik. Sebab dengan mengenal peserta didik, diharapkan dalam pelaksanaan pembelajaran IPS guru mampu memilih media yang cocok dengan karakteristik kecerdasan emosional yang dimilliki; (3) Penggunaan media lingkungan sekitar untuk pembelajaran IPS dilakukan secara berkelanjutan agar tercipta pembelajaran yang efektif. Dengan demikian diharapkan kepada guru untuk mampu mengembangkan materi-materi lain sehingga pembelajaran IPS dapat berjalan dengan baik dan tujuan pembelajaran dapat tercapai; (4) Penggunaan media lingkungan sekitar dalam pembelajaran IPS akan mampu mengatasi kejenuhan, dan kurangnya aktivitas siswa dalam pembelajaran. Dengan demikian dapat menepis anggapan bahwa mata pelajaran IPS adalah mata pelajaran yang membosankan; (5) Kepada peneliti selanjutnya disarankan agar kiranya dapat melanjutkan penelitian ini dengan media yang berbeda untuk kelompok peserta didik dengan kemampuan rata-rata ke bawah atau dengan media yang sama untuk kelompok peserta didik di atas rata-rata, untuk menambah khazanah pengetahuan para guru dalam menentukan media yang tepat digunakan dalam pelaksanaan proses pembelajaran di kelas.

\section{UCAPAN TERIMA KASIH}

Dalam kesempatan ini penulis mengucapkan terima kasih kepada berbagai pihak yang telah membantu dalam pelaksanaan penelitian ini, khususnya pihak SMP Negeri 5 Cilacap dan SMP Negeri 2 Cilacap. Penulis juga mengucapkan terima kasih kepada pembimbing serta dewan redaksi Jurnal Socia atas kesempatan yang diberikan sehingga paper ini dapat diterbitkan pada Jurnal Socia edisi Mei 2015.

\section{DAFTAR PUSTAKA}

Chiras D. 1991. Environmental science. California: Benjamin cummings company Inc. Daryanto. 2010. Media pembelajaran. Yogyakarya: Gava Media

Ellis, A. K. 1998. Teaching and learning elementary sosial studies (sixth edition). USA: seattle Pacific University.

Ghozali, I. 2011. Aplikasi Analisis Multivariate dengan Program IBM SPSS 19. Semarang: Universitas Diponegoro.

Goleman, D. 1999. Kecerdasan emosi untuk mencapai puncak prestasi. Jakarta: Gramedia Pustaka Utama.

Hamalik, 0. 2008. Proses Belajar Mengajar. Jakarta: Bumi Aksara

Shapiro, E.L. 1998. Mengajarkan emotional intelligences pada anak. (terjemahan Alex Tri Kantjono). Jakarta: PT Gramedia

Slameto. 2010. Belajar dan faktor-faktor yang mempengaruhinya. Jakarta: Rineka Cipta

Sudjana, N. \& Rivai, A. (2009). Media pengajaran. Jakarta: Sinar baru Aglensindo

Sudrajat, A. 2013. Pendekatan Saintifik/ Ilmiah dalam Proses Pembelajaran. akhmadsudrajat.wordpress.com/2013/07/18/ pendekatan-saintifikilmiah-dalam-prosespembelajaran/. diunduh tanggal 15 September 2013.

Sugiyono. 2009. Penelitian Kuatitatif Kualitatif dan R\&D. Bandung: Alfabeta.

Sukardi. 2012. Metodologi penelitian pendidikan kompetensi dan praktiknya. Jakarta: Bumi Aksara 